\title{
The effects of situational leadership and self-efficacy on the improvement of teachers' work productivity using correlation analysis and SITOREM
}

\author{
Rais Hidayat ${ }^{1 *}$, Soewarto Hardhienata ${ }^{1}$, Yuyun Elizabeth Patras ${ }^{1}$, \\ Rindu Rahayu Agustin ${ }^{2}$. \\ ${ }^{1}$ Universitas Pakuan, Indonesia \\ ${ }^{2}$ State Elementary School, Bogor, Indonesia \\ ${ }^{*}$ Corresponding author, $\equiv$ e-mail: rais72rais@gmail.com
}

\begin{abstract}
This research aimed to determine the positive correlation of situational leadership and selfefficacy with the improvement of teacher work productivity. The quantitative method with correlation analysis were employed, furthermore the Scientific Identification Theory to Conduct Operation Research in Education Management (SITOREM) was applied to determine the priorities. The population includes all the elementary school teachers which are civil servants (PNS) in Bogor, Indonesia while 105 were selected as samples. The findings showed there is a positive correlation between situational leadership and teacher work productivity with a correlation coefficient of 0.783 , and between self-efficacy and teacher work productivity with 0.782 . This, therefore, means these two factors are influential in increasing the productivity of teachers. The novelty of this research was the use of SITOREM to highlight 7 indicators prioritized to be improved including leader behavior, delegation, direction, teacher achievement, facility use, efficiency, and managerial ability.
\end{abstract}

Keywords: Self-efficacy, situational leadership, SITOREM, teacher work productivity.

How to Cite: Hidayat, R., Patras, Y., Hardhienata, S., \& Agustin, R. (2020). The effects of situational leadership and self-efficacy on the improvement of teachers' work productivity using correlation analysis and SITOREM. COUNS-EDU: The International Journal of Counseling and Education, 5(1), 6-14. DOI: http://.doi.org/10.23916/0020200525310

This is an open access article distributed under the Creative Commons Attribution License, which permits unrestricted use

distribution, and reproduction in any medium, provided the original work is properly cited. (C2020 by author.

\section{Introduction}

The quality of education has been reported to be highly dependent on several factors and one of the most important is the work behavior of teachers which is associated with their work productivity (Hanushek \& Ettema, 2017). For example, despite the provision of adequate facilities and a perfect curriculum by the government or educational organization, a low teachers' behavior has the ability to reduce the quality of education (Etomes \& Molua, 2019). This, therefore, means the theme of teacher work productivity is very important to the education process (Harris \& Sass, 2014) and needs to be researched and developed to improve the quality of education (Sass, Semykina, \& Harris, 2014).

The work productivity of the teacher determines educational outcomes (Mesiono, 2019) based on the mental attitude of making life better. Teachers are expected to maintain high work productivity due to its effect on the quality of education (Ndugu, 2014) as well as the democratic society (Camacho \& Parham, 2019). 
There are limited research related to teachers' work productivity (Abdullah, 2019) despite the fact it is influenced by different factors including the school leadership, facilities, teachers' training, and the teachers' condition (Kagwiria, 2013).

Productivity has always been studied in relation to the private sector before it was introduced into the education sector (Hanushek \& Ettema, 2017). Therefore, labor productivity was defined as a measure of the success of labor producing a product over a certain period (Sumarsono, 2009) while education productivity is related to quantitative and qualitative production of graduates by schools (Sedarmayanti, 2001). The concept basically includes a mental attitude encouraging avoidance of complacency but investment in continuous self-development to improve work skills (Sutrisno, 2010).

The time spent on leave (absence) due to an illness and at work but with a decreased level of productivity is considered to be the same (Bombardier, Zhang, Lacaille, \& Osborne, 2009). This, therefore, means work productivity is the difference between input and output (Hasibuan, 2010) as well as the ability to produce more quality (Anoraga, 2009). Moreover, in relation to education, it is the ability to provide produce learners with relevant skills and expertise to create quality lives and provide benefits to the environment (Aan Komariah, 2008).

Productivity is, however, inseparable from human resource management activities (Ivancevich \& Matteson, 2013) due to the involvement of input, activities of humans, and results such as the achievement of learning outcomes (Sass et al., 2014). The concept has also been reported to be very important in management studies (Hanaysha, 2016). However, for the purpose of this study, teacher work productivity was defined as a measure of the success obtained by comparing the efforts inputted by a teacher with the output over a certain period.

Situational leadership is model of leading that integrates both the directive and supportive dimensions, each of which is applied correctly in appropriate situations (Ghazzawi, Shoughari, \& Osta, 2017). It emphasizes the readiness, willingness, and ability of followers to conduct certain tasks (S. P. R. and T. A. Judge, 2016). According to Rivai \& Mulyadi (2003), leaders are required to have diagnostic skills to understand human behavior (Mulyadi, Veithzal Rivai, 2009). However, Siagian (2003) stated that the effectiveness of leadership is determined by the ability to read the situation and adjust the style to meet the present demands (Siagian, 2010). Gibson (Gibson, Ivancevich, Donnelly, \& Organizations, 2006) also showed this leadership model focuses on the followers and their level of maturity.

Situational leadership theory showed effective leaders have many styles of leading based on the readiness of their followers and some of these include telling, selling, participating, and delegating (Steven L. McShane, 2018). This further allows its influence on several activities of an organization (Amanchukwu, Stanley, \& Ololube, 2015) Therefore, for the purpose of this study, situational leadership was defined as a way of influencing subordinates using different leadership styles such as telling, selling, participating, and delegating depending on the current situation.

Another important factor to achieve productivity is self-efficacy (Hidayat, Putra, \& Patras, 2018). It was defined to be the self-belief owned by an individual to have the ability to conduct a specific task successfully (Colquitt, Lepine, \& Wesson, 2015). Moreover, Stroch (2002) also defined it as a person's belief to engage in work behavior appropriately by producing a specified level of performance (Linda K. Stroh, Gregory B. Northcraft, 2002). Some characteristics of people with high self-efficacy include possessing the abilities needed, making necessary efforts, working without outside influences preventing the achievement of the required level of performance (Linda K. Stroh, Gregory B. Northcraft, 2002), believing in success, working harder, more creativity, having motivation at work (S. P. R. and T. A. Judge, 2016), confidence, motivation, direction, and endurance in completing tasks (Jennifer M. George, 2012). Furthermore, according to Luthans (2011), self-efficacy is influenced by mastery of experience or achievement of performance, diverse modeling, social persuasion, as well as physiological and psychological arousal (Luthans, 2011). It can be improved through training, coaching, providing freedom and responsibility, showing an example, giving praise, motivating, reducing stress, caring, and providing assistance (Newstrom, 2007).

Self-efficacy and leadership have been reported to have a positive influence on productivity (Momeni, 2014). Several studies showed self-efficacy correlates with pro-social behavior (Gaol, 2018), achieving goals (Diaconu-gherasim, Mă irean, \& Brumariu, 2019), organizational citizenship behavior

The effects of situational leadership and self-efficacy on the improvement of teachers' work... | 7 Indonesian Counselor Association (IKI) | DOI: https://doi.org/10.23916/0020200525310 
(Mansor, 2013), and work productivity of teachers (Tamuri, 2019). Meanwhile, leadership has also been discovered to have a positive relationship with productivity (Veliu, Manxhari, Demiri, \& Jahaj, 2017), employee motivation towards productivity (Eyal \& Roth, 2010), and teamwork (Hidayat et al., 2018). The novelty of this study is, therefore, the use of mixed methods including correlational research and Scientific Identification Theory to Conduct Operational Research in Education Management (SITOREM) to determine the indicators to be prioritized in order to improve teachers' work productivity.

\section{Method}

The research aimed to determine the efforts toward improving teachers' work productivity through the use of a quantitative method with correlation analysis and SITOREM (Scientific Identification Theory to Conduct Operation Research in Education Management (Hardhienata, 2017). The independent variables were situational leadership (X1) and self-efficacy (X2), while the dependent variable (Y) was the work productivity. This research was conducted on a sample of 105 elementary school teachers that are civil servants (PNS) in Bogor, Indonesia.

Data were collected using three questionnaire instruments including: 1) The teacher's work productivity instrument assessed by the teacher's supervisor, consisting of 6 indicators which are teacher achievement, work quality, utilization of infrastructure, efficiency, managerial ability, and performance, with 17 items ; 2) The transactional leadership instrument was conducted by the teacher to assess the principal, consisting of 5 indicators which are the leader behavior, saying, directing, participating, and delegating, with 32 items; 3) The self-efficacy instrument was assessed by the teacher and it consists of 6 indicators which are self-confidence, self-ability, high goals, high-achievement, hard work, and ability to find a solution, with 33 items. Moreover, the level of reliability for the teacher's work productivity instrument was 0.954 , situational leadership was 0.948 and self-efficacy was 0.948 and a measurement scale from 1 to 5 (very good) was used in all the instruments.

The quantitative data were analyzed using descriptive and inferential statistics while the hypotheses were tested after the normality and variance homogeneity have been estimated. Moreover, the SITOREM was applied after the correlation-regression analysis (Hardhienata, 2017). The basic considerations to derive suggestions and priorities for improvements include three criteria which were: 1) The strength of the relationship between the independent and dependent variables obtained from data analysis conducted using a correlational statistical method; 2) Priority order of the indicators for each variable arranged based on input from expert opinion and analysis, an; 3) Indicator values obtained from the field research (Hardhienata, 2017).

Therefore, the SITOREM analysis was expected to recommend (a) good indicators to be maintained, and (b) bad indicators to be corrected in the order of priority for improvement (Hardhienata, 2017). The SITOREM analysis is generally explained in the following figure (Hardhienata, 2017).

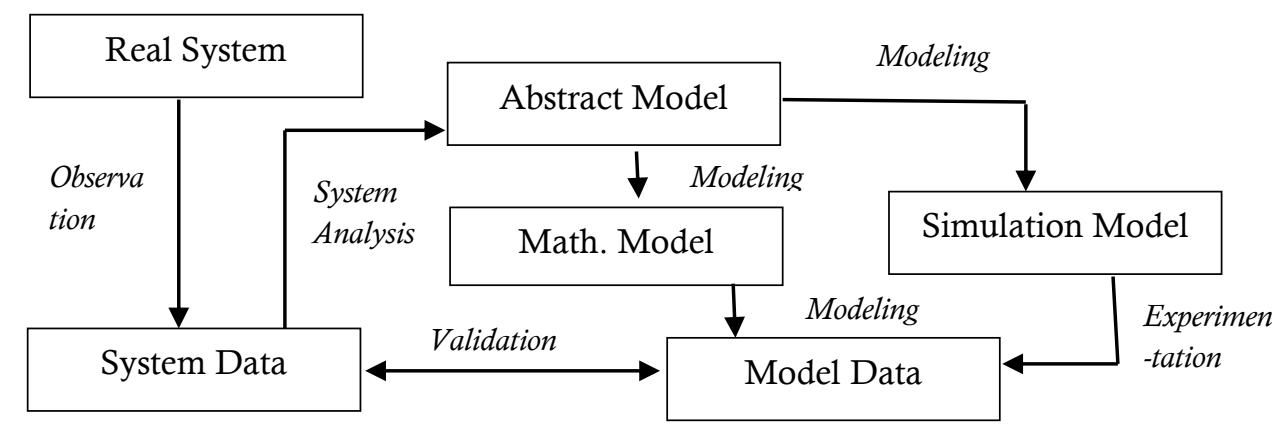

Figure 1. The scientific identification theory (Hardhienata, 2017) 


\section{Results and Discussions}

\section{Descriptive statistics results}

The teachers' work productivity research instrument consists of 16 valid items and this means its lowest theoretical score is 16 , the highest is 80 , and the median is 48 . However, the research score empirically moved from the lowest score of 43 , highest at 80 , and the median at 63 and the indicates the empirical median score of teacher work productivity is above the theoretical and can, therefore, be categorized as high.

The situational leadership research instrument consists of 32 valid items which means it has the lowest theoretical score of 32, highest at 160, and the median score at 96 . Meanwhile, the research score empirically moves from the lowest score of 95 and highest at 153 to produce a median score of 130 and this shows the empirical situational leadership's median score is above the theoretical and can, therefore, be categorized as high.

The self-efficacy research instrument consists of 33 valid items which meant it has the lowest theoretical score of 33 , highest at 165 to have a median score of 99. Meanwhile, the research score empirically moved from the lowest score of 110 and highest at 162 to produce a median score of 139 . This shows the empirical median score of self-efficacy is above the theoretical and can, therefore, be categorized as high.

Table 1. Results of descriptive statistics

\begin{tabular}{lccc}
\hline & Teacher's work productivity & Situational leadership & Self-efficacy \\
\hline Average & 62.66 & 126.99 & 138.55 \\
\hline Median & 63 & 130 & 139 \\
\hline Mode & 60 & 131 & 140 \\
\hline Standard Deviation & 6.86 & 12,60 & 11.81 \\
\hline Variance & 47.11 & 158.82 & 139.34 \\
\hline Range & 37 & 58 & 52 \\
\hline Minimum Value & 43 & 95 & 110 \\
\hline Maximum Value & 80 & 153 & 162 \\
\hline Total & 6579 & 13.334 & 14.548 \\
\hline
\end{tabular}

\section{Testing requirements for analysis}

\section{Normality test}

The estimated error normality test (Y-Ŷ1) showed the teacher work productivity variable on the situational leadership variable was calculated to have an $\mathrm{L}$ value of 0.049 while the $\mathrm{L}$ table is 0.087 and since the normal requirement is the $\mathrm{L}$ value $<\mathrm{L}$ table, therefore, it is normally distributed.

The estimated error normality test (Y-Ŷ2) showed the teacher work productivity variable on the selfefficacy variable was calculated to have an $L$ value of 0.048 while the $L$ table is 0.087 and since the normal requirement is the $\mathrm{L}$ value $<\mathrm{L}$ table, therefore, it is normally distributed.

\section{Homogeneity Test}

The homogeneity test of the variance of teacher work productivity variables on situational leadership showed a value of $X_{\text {value }}=49.11$ while $X^{2}$ table at $\alpha=0.05=51.00$. Therefore, this relationship was declared homogeneous.

The homogeneity test of the variance of teacher work productivity variables on self-efficacy showed a value of $X_{\text {value }}^{2}=47.23$ while $X^{2}$ table at $\alpha=0.05=51.00$. Therefore, this relationship was declared homogeneous.

\section{Hypothesis test}

- The correlation of situational leadership with teacher work productivity. The correlation of situational leadership variables (X1) with teacher work productivity variables (Y) was determined by the 
coefficient of determination $\left(\mathrm{r}_{\mathrm{y1}}^{2}\right)$ and a value of 0.613 was obtained. This means the contribution of situational leadership to the teacher work productivity variable is relatively strong. Furthermore, the correlation test showed the $t$ value was 20.52 while the $t$ table is 1.98 and this further confirms the correlation to be significant. Therefore, it can be concluded there is a significant positive correlation of situational leadership on teacher work productivity.

- Correlation of self efficacy with teacher work productivity. The correlation of self-efficacy variables (X2) with teacher work productivity variables $(\mathrm{Y})$ was determined by the coefficient of determination $\left(\mathrm{r}_{\mathrm{y} 2}^{2}\right)$ and a value of 0.612 . This shows the contribution of self-efficacy to the teacher work productivity variable is relatively strong. Moreover, the correlation test also showed the $t$ count is 20.43 while the $t$ table is 1.98 and this means the correlation is significant. Therefore, it can be concluded there is a significant positive correlation of self-efficacy on teacher work productivity.

- Partial correlation test. A partial correlation was found between situational leadership (X1) with teacher work productivity $(\mathrm{Y})$ using self-efficacy $\left(\mathrm{X}_{2}\right)$ as control as observed with the $\left(\mathrm{ry}_{12}\right)$ value of 0.679 while the significance test showed $t_{\text {value }}=12.800>t_{\text {table }}=1.98$ at $\alpha=0.05$. Therefore, the correlation of situational leadership with teacher work productivity was found not to be influenced by self-efficacy.

A partial correlation between self-efficacy (X2) with teacher work productivity (Y) using situational leadership $\left(\mathrm{X}_{1}\right)$ as a control $\left(\mathrm{ry}_{12}\right)$ produced a value of 0.672 while the significance test showed $\mathrm{t}_{\text {value }}=$ $12.417>\mathrm{t}_{\text {table }}=1.98$ at $\alpha=0.05$. This, therefore, means the correlation between self-efficacy and teacher work productivity is not influenced by situational leadership.

\section{Priority for improvement}

SITOREM has been used in previous studies to determine priorities in improving teacher innovation (Setyaningsih, Sukanti, \& Hardhienata, 2019), teacher performance (Darmawi, Hardhienata \& Retnowati, 2019) and motivation, transformational leadership, and personality (Djami, Hardhienata, \& Tukiran, 2019).

The correlational research showed it is possible to improve teacher work productivity through situational leadership and self-efficacy and the application of SITOREM as shown in Figure 2 shows there are certain indicators to be maintained and those to be improved. They are associated with independent variables, situational leadership and self-efficacy and the required to be retained include (1) participating, (2) telling, (3) achievement, (4) solutions, (5) self-confidence, (6) working hard, (7) self-ability, (8) goals, (9) work quality, and (10) performance while the 7 prioritized for improvement are (1) leader behavior, (2) delegating, (3) directing, (4) teacher achievement, (5) using facility, (6) efficiency, and (7) managerial ability.

The strength of situational leadership's correlation with teacher work productivity is indicated with the correlation coefficient of 0.783 and this is in line with the results of the research in Lebanon which showed situational leadership has a strong influence on work productivity (Ghazzawi et al., 2017). Moreover, other findings have also suggested leadership style generally has a significant effect on productivity (Shamaki, 2015) especially in relation to personality, motivation, and ability (Adu, Olatundun, \& Adu, 2017). This was further supported by the theory of Shane \& Glinow (2008) that effective leaders have many variations of styles to deal with the readiness of followers such as the ability or willingness of employees or work teams to complete certain tasks (Steven L. McShane, 2018). Leadership in organizations has also been identified to have the ability of influencing many things including work productivity and performance (Adu et al., 2017). The findings of this research showed the principal as a leader is required to have a method of influencing the subordinates (Eren, 2012) through the use of different styles (Marks \& Printy, 2015) to have the most impact (Dempster, Townsend, Johnson, \& Bayetto, 2017). Some of these styles include orders, support, delegation of authority, and other ways to influence the productivity of the teachers (Susanthi \& Setiawan, 2014). 


\author{
Situational leadership \\ 1. Behavior as a leader: \\ (24\%), $(3,92)$ \\ 2. Telling: $(22 \%),(4,22)$ \\ 3. Directing: $(19,5 \%),(3,86)$ \\ 4. Participating: $(19,5 \%)$, \\ $(3,71)$ \\ 5. Delegating: $(15 \%),(4,12)$
}

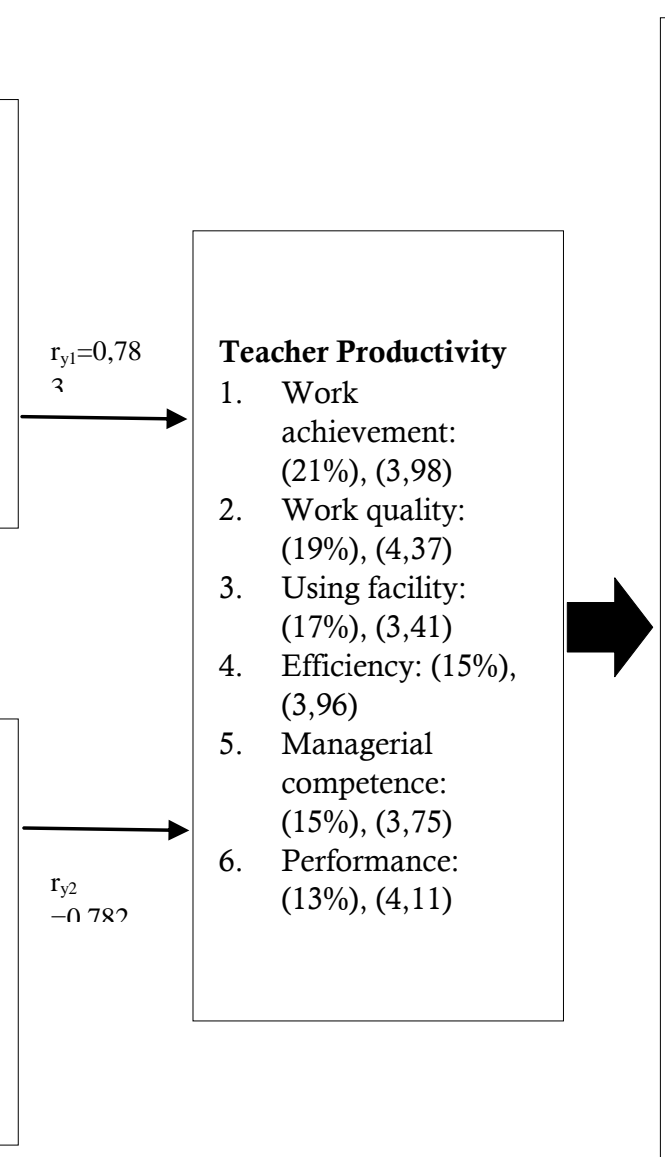

Indicators to retain:

1. Participating: $(19,5 \%)$, $(3,71)$

2. Telling: $(22 \%),(4,22)$

3. Achievement : $(16 \%)$, $4,14)$

4. Solution: $(11 \%),(4,20)$

5. Confidence: $(20 \%),(4,42)$

6. Hard work: $(16 \%),(4,03)$

7. Competence: $(20 \%)$, $(4,40)$

8. Goal : $(17 \%),(4,11)$

9. Work quality: (19\%), $(4,37)$

10. Performance: $(13 \%)$, $(4,11)$

Indicators to improve:

1. Behavior as a leader: (24\%), $(3,92)$

2. Delegating: $(15 \%),(4,12)$

3. Directing: $(19,5 \%),(3,86)$

4. Using facility: (17\%), $(3,41)$

5. Work achievement: $(21 \%),(3,98)$

6. Efficiency: $(15 \%),(3,96)$

7. Managerial competence: $(15 \%),(3,75)$

Figure 2. Indicators list to retain and improve based on SITOREM

The strength of the correlation of self-efficacy with teacher work productivity is indicated with the correlation coefficient of 0.782 and this is in agreement with the findings of another research that showed self-efficacy have a major effect on employee performance (T. A. Judge, Jackson, Shaw, Scott, \& Rich, 2007), has the ability to increase employees' productivity (Mensah, 2013), job satisfaction and commitment (Mukhtar \& Sujanto, 2018), and ability to compete (Soenanto, Tuntas Widyo, Djabir Hamzah, Mahlia Muis, 2016). It is also in line with the theory of Gibson, et al (2006) which states that self-efficacy is a person's belief to have the ability of working effectively in certain situations (Gibson et al., 2006). It has also been reported to be important to the development of organizational performance (Bandura, 1999), therefore, it needs to be continually developed and cultivated (Djigi, Stojiljkovi, \& Doskovi, 2014). This strong correlation shows the problem of low teacher work productivity can be solved by improving self-efficacy (Soenanto, Tuntas Widyo, Djabir Hamzah, Mahlia Muis, 2016). Therefore, efforts to improve the characteristics of self-efficacy (Jaiswal \& Dhar, 2015) such as self-confidence, selfability, high goals, the achievement of goals, working hard and finding solutions need to be continuously improved in the teachers (T. A. Judge et al., 2007).

Moreover, 7 priorities were recommended to be retained and the first is improving the leader's behavior. This is not surprising because other studies have shown its significant positive effects on organizational (Shamaki, 2015) and employee performance (Mustafa TAŞLIYAN \& HARBALIOĞLU, 2017). This is associated with the ability of the leaders to use different strategic and tactical behaviors to run the organization (NIKOLOSKI, 2015). This, therefore, means their behavior plays a central role (Smith \& Squires, 2016) and also has the ability to influence the ethics of the members (Hidayat, 2017). 


\section{Conclusions}

Increasing teacher work productivity is very important due to its contribution to the quality of education. This research showed this is achievable by increasing situational leadership and self-efficacy while 10 indicators were recommended to be retained using SITOREM and they are (1) participating, (2) telling, (3) achievement, (4) solutions, (5) self-confidence, (6) ) working hard, (7) self-ability, (8) goals, (9) work quality, and (10) performance while 7 others were prioritized for improvement and they include (1) leader behavior, (2) delegating, (3) directing, (4) teacher achievement, (5) infrastructure, (6) efficiency, and (7) managerial ability.

\section{References}

Aan Komariah, C. T. (2008). Visionary Leadership Menuju Sekoah Efektif. Bandung: Bumi Aksara.

Abdullah, N. N. (2019). The Impact Of Staff Training And Development On Teacher's Productivity. Economics, Management and Sustainability, (May). https://doi.org/10.14254/jems.2019.4-1.4

Adu, K. O., Olatundun, S. A., \& Adu, E. O. (2017). Factors Hindering Teachers ' Productivity in Public Secondary Schools Factors Hindering Teachers ' Productivity in Public. Journal of Social Sciences ISSN:, 49, 70-76. https://doi.org/10.1080/09718923.2016.11893599

Amanchukwu, R. N., Stanley, G. J., \& Ololube, N. P. (2015). A Review of Leadership Theories , Principles and Styles and Their Relevance to Educational Management. Management, 5(1), 6-14. https://doi.org/10.5923/j.mm.20150501.02

Anoraga, P. (2009). Psikologi Kerja. Jakarta: Rineka Cipta.

Bandura, A. (1999). Self-Efficacy in Changing Societies. Delhi: Cambridge University Press.

Bombardier, C., Zhang, W., Lacaille, D., \& Osborne, R. H. (2009). The Journal of Rheumatology Measuring Worker Productivity : Frameworks and Measures. The Journal of Rheumatology, 36(9). https://doi.org/10.3899/jrheum.090366

Camacho, D. A., \& Parham, B. (2019). Urban teacher challenges : What they are and what we can learn from them. Teaching and Teacher Education, 85, 160-174. https://doi.org/10.1016/j.tate.2019.06.014

Colquitt, J. A., Lepine, J. A., \& Wesson, M. J. (2015). Organizational Behavior: Improving Performance and Commitment. New York: McGraw Hill Education.

Darmawi, Hardhienata, S., \& Retnowati, R. (2019). Using Scientific Identification Theory for Operational Research in Education for analyzing Teachers ' Performance. International Journal of Managerial Studies and Research (IJMSR), 7(4), 21-28.

Dempster, N., Townsend, T., Johnson, G., \& Bayetto, A. (2017). Leadership and Literacy: Principals, Partnerships and Pathways to Improvement. Gewerbestrasse: Springer International Publishing.

Diaconu-gherasim, L. R., Mă irean, C., \& Brumariu, L. E. (2019). Quality of teachers' and peers ' behaviors and achievement goals : The mediating role of self-efficacy. Learning and Individual Differences, 73(June), 147-156. https://doi.org/10.1016/j.lindif.2019.06.001

Djami, M. E. U., Hardhienata, S., \& Tukiran, M. (2019). Improvement of Job Satisfaction through Transformational Leadership, Personality, and Achievement Motivation by Using Scientific Identification Theory of Operation Research in Education Management ( SITOREM ). International Journal of Managerial Studies and Research (IJMSR), 7(4), 62-70.

Djigi, G., Stojiljkovi, S., \& Doskovi, M. (2014). Basic personality dimensions and teachers ' self-efficacy. Procedia - Social and Behavioral Sciences, 112(Iceepsy 2013), 593-602. https://doi.org/10.1016/j.sbspro.2014.01.1206

Eren, E. (2012). Innovative Leadership for the Twenty-First Century. International Conference on Leadership, Technology and Innovation Management, 41, 1-14. https://doi.org/10.1016/j.sbspro.2012.04.001

Etomes, S. E., \& Molua, E. L. (2019). Strategies for Enhancing the Productivity of Secondary School Teachers in South West Region of Cameroon. Journal of Education and Learning, 8(1), 109-119. https://doi.org/10.5539/jel.v8n1p109

Eyal, O., \& Roth, G. (2010). Principals ' leadership and teachers 'motivation. JEA, 49(3), 256-275. https://doi.org/10.1108/09578231111129055

Gaol, M. (2018). The relationship between emotional intelligence, self efficacy and prosocial behaviour on interpersonal conflict management. The International Journal of Counseling and Education, 3(4), 121125.

Ghazzawi, K., Shoughari, R. El, \& Osta, B. El. (2017). Situational Leadership and Its Effectiveness in 
Rising Employee Productivity : A Study on North Lebanon Organization. Human Resource Management Research, 7(3), 102-110. https://doi.org/10.5923/j.hrmr.20170703.02

Gibson, J. L., Ivancevich, J. M., Donnelly, J. H., \& Organizations, R. K. (2006). Organizations, Behavior, Sructure and Proceses. Boston: McGraw-Hill.

Hanaysha, J. (2016). Improving employee productivity through work engagement : Evidence from higher education sector Improving employee productivity through work engagement : Empirical evidence from higher. Management Science Letters, (January). https://doi.org/10.5267/j.msl.2015.11.006

Hanushek, E. A., \& Ettema, E. (2017). Defining Productivity in Education : Issues and Illustrations. The American Economist, 62(2), 165-183. https://doi.org/10.1177/0569434516688207

Hardhienata, S. (2017). The development of scientific identification theory to conduct operation research in education management. IORA International Conference on Operations Research. https://doi.org/10.1088/1742-6596/755/1/011001

Harris, D. N., \& Sass, T. R. (2014). Economics of Education Review Skills, productivity and the evaluation of teacher. Economics of Education Review, 40, 183-204. https://doi.org/10.1016/j.econedurev.2014.03.002

Hasibuan, M. (2010). Organisasi dan Motivasi. Jakarta: Bumi Aksara.

Hidayat, R. (2017). Perilaku Etis Dosen dalam Perspektif Efikasi Diri, Kepemimpinan, dan Komunikasi Interpersonal. Pedagonal, 1(1), 37-44.

Hidayat, R., Putra, K. S., \& Patras, Y. E. (2018). Improving Team Cohesiveness Based on Perspective of Self-efficacy and Leadership Behaviour, Proceeding(Aes 2017), 308-312.

Ivancevich, J. M., \& Matteson, M. T. (2013). Organizational Behavior and Management Tenth Edition. New York: McGraw-Hill Irwin.

Jaiswal, N. K., \& Dhar, R. L. (2015). Transformational leadership , innovation climate , creative selfefficacy and employee creativity: A multilevel study. International Journal of Hospitality Management, 51, 30-41. https://doi.org/10.1016/j.ijhm.2015.07.002

Jennifer M. George, G. R. J. (2012). Understanding and Managing Organizatioanl Behavior. Boston: Printice Hall.

Judge, S. P. R. and T. A. (2016). Organizational Behavior. Tokyo: Pearson.

Judge, T. A., Jackson, C. L., Shaw, J. C., Scott, B. A., \& Rich, B. L. (2007). Self-Efficacy and WorkRelated Performance: The Integral Role of Individual Differences. Journal of Applied Psychology, 92(1), 107-127. https://doi.org/10.1037/0021-9010.92.1.107

Kagwiria, K. J. (2013). Teacher' s Productivity in Promoting Quality Education in Public Primary Schools in Kenya. Academic Journal of Interdisciplinary Studies, 2(2), 365-378. https://doi.org/10.5901/ajis.2013.v2n2p365

Linda K. Stroh, Gregory B. Northcraft, M. A. N. (2002). Organizational Behavior: A Management Challenge Third Edition. New Jersey 07430: Lawrence Erlbaum Associates, Inc., Publishers.

Luthans, F. (2011). Organizational Behavior An Evidence-Based Approach. New York: McGraw Hill Irwin. https://doi.org/10.1002/9781118785317.weom060151

Mansor, A. (2013). Mediating Effect of Self-Efficacy on Self-Leadership and Teachers ' Organizational Citizenship Behavior: A Conceptual Framework. International Journal of Economics, Business and Management Studies, 2(1), 1-11.

Marks, H. M., \& Printy, S. M. (2015). Principal Leadership and School Performance : An Integration of Transformational and Instructional Leadership. Educational Administration Quarterly, 39(3), 370-397. https://doi.org/10.1177/0013161X03253412

Mensah, A. O. (2013). The Influence of Employees' Self-Efficacy on Their Quality of Work Life: The Case of Cape Coast, Ghana. International Journal of Business and Social Science, 4(2).

Mesiono. (2019). The Influence of Job Satisfaction on the Performance of Madrasah Aliyah ( Islamic Senior High School ) Teachers. Tadris: Jurnal Keguruan Dan Ilmu Tarbiyah, 4(1), 107-116. https://doi.org/10.24042/tadris.v4i1.4388

Momeni, M. (2014). The Effect Of Employees' Self-Efficacy On Innovative Work Behavior At Social Security Organization Employees In Ardabil Province. Kuwait Chapter of Arabian Journal of Business and Management Review, 3(8), 29-32.

Mukhtar, M., \& Sujanto, B. (2018). The Influence of Self Efficacy , Job Satisfaction and Organizational Commitment Toward Organizational Citizenship Behavior ( Ocb ) of Teachers Of Private Vocational Schools in South Jakarta. International Journal of Scientific Research and Management 
(IJSRM), 06(06), 406-414. https://doi.org/10.18535/ijsrm/v6i6.el06

Mulyadi, Veithzal Rivai, D. (2009). Kepemimpinan dan Perilaku Organisasi. Jakarta: Rajawali Press.

Mustafa TAŞLIYAN, B. H., \& HARBALIOĞLU. (2017). The Effect of Servant Leadership on Organizational Citizenship Behaviour And Performance of Employee: A Research on Hotel Managements In Gaziantep. The Journal of International Social Research, 9(44), 1232-1240.

Ndugu, M. M. (2014). Quality and Productivity of Teachers in Selected Public Secondary Schools in Kenya. Mediterranean Journal of Social Sciences, 5(5), 103-116. https://doi.org/10.5901/mjss.2014.v5n5p

Newstrom, J. (2007). Organizational Behavior, Human Behavior at Work. (McGraw-Hill, Ed.). Boston.

NIKOLOSKI, K. (2015). Leadership And Management: Practice Of The Art Of Influence. Academica Brâncuşi" PUBLISHER, II(1), 31-39.

Sass, T. R., Semykina, A., \& Harris, D. N. (2014). Economics of Education Review Value-added models and the measurement of teacher productivity. Economics of Education Review, 38, 9-23. https://doi.org/10.1016/j.econedurev.2013.10.003

Sedarmayanti. (2001). Sumber Daya Manusia dan Produktivitas Kerja. Bandung: Mandar Maju.

Setyaningsih, S., Sukanti, D., \& Hardhienata, S. (2019). Teacher' s Innovation Improvement through the Development of Organizational Climate and Emotional Intelligence Using Correlation Statistical Analysis and Sitorem Method. Advances in Social Science, Education and Humanities Research, 253(Aes 2018), 45-49.

Shamaki. (2015). Influence of Leadership Style on Teacher' s Job Productivity in Public Secondary Schools in Taraba State, Nigeria. Journal of Education and Practice, 6(10), 200-204.

Siagian, S. P. (2010). Teori dan Praktek Kepemimpinan. Jakarta: Rineka Cipta.

Smith, B. S., \& Squires, V. (2016). The Role of Leadership Style in Creating a Great School. SELU Research Review Journal, 1(1), 65-78.

Soenanto, Tuntas Widyo, Djabir Hamzah, Mahlia Muis, N. B. (2016). The Influence of Telecommuting Systems , Self- Efficacy and the Quality of Management on Work Productivity and the Competitiveness of Organizational Perspectives in Multinational Companies in Jakarta, Indonesia. Scientific Research Journal (SCIRJ), IV(Iii), 43-52.

Steven L. McShane, M. A. V. G. (2018). Organizational Behavior: Emerging Knowledge Global Reality (eight edition). NY 10121.

Sumarsono, S. (2009). Teori dan Kebijakan Publik Ekonomi Sumber Daya Manusia. Yogyakarta: Graha Ilmu.

Susanthi, N. I., \& Setiawan, A. (2014). The Effect of Leadership Style on Motivation to Improve the Employee Performance. Jurnal Manajemen Transportasi \& Logistik (JMTransLog), 01(03), 221-226.

Sutrisno, E. (2010). Manajemen Sumber Daya Manusia. Jakarta: Kencana.

Tamuri, A. H. (2019). The Significant Correlation between Self Efficacy and the Role of Islamic Education Teachers as a Society Change Agent Noornajihan Jaafar Nurul Asia Fasehah Muhamad Azhar Haji Ahmad Nur Hanani Hussin Mohd Khamal Md . Daud Maziahtusima Ishak. Mediterranean Journal of Social Sciences, 2117, 83-89. https://doi.org/10.2478/mjss-2019-0044

Veliu, L., Manxhari, M., Demiri, V., \& Jahaj, L. (2017). The Influence Of Leadership Style S On Employee' S Performance. Vadyba Journal of Management, 31(2), 59-69. 